\title{
THE LAW, THE CONSTITUTION AND LEGAL EDUCATION IN THE TWENTY- FIRST CENTURY
}

\author{
Sir Kenneth Keith ${ }^{*}$
}

Sir Kenneth Keith gave the lecture on which this paper is based as part of the 1999 Centennial Alumni Lecture series. Using the career of the first Dean of Law at Victoria University College as his inspiration, Sir Kenneth deals with a wide range of issues which all those in the law, be they judges, practitioners, teachers or students will have to address.

\section{THE FIRST DEAN OF LAW}

My task is to explore the law, one of the founding disciplines of the University. I begin by mentioning the first Dean of Law who, in his eight years here, was also the first Professor of Mathematics, the first chairman of the Professorial Board, and the first and only Professor of Astronomy. He was later a Professor of Mathematical Physics at Columbia University in New York and the President of the Massachusetts Institute of Technology.

I begin with Richard Cockburn Maclaurin, both to give a sense of one of the very great members of this University and of his time and to introduce two contrasting ways of thinking about the law, the constitution and legal education in the next century.

Ernest Rutherford was a contemporary of Maclaurin at Cambridge in the 1890s. He had particular reason to know of the Maclaurin family since he had received the 1851 Exhibition Scholarship which took him to Cambridge only when Richard's older brother

* $\quad$ Member of the Faculty of Law, Victoria University of Wellington 1962-1964, 1966-1991; Professor Emeritus 1991; Judge of the Court of Appeal of New Zealand; Associé de l'Institut de Droit International. This paper is based on one of the Alumni lectures of 1999 given in June 1999. The series addressed aspects of the founding disciplines of the University. Dr George Barton QC, Nicola Grant, John Lekner, Sir Geoffrey Palmer and Warren Young provided valuable comments on an earlier version of this paper. 
James had turned it down. He made a valuable general comment about Maclaurin's character and gave a specific instance of it. Rutherford's general comment was this: ${ }^{1}$

I was from the first impressed by his unusual reticence - I might almost say secrecy - about his own doings and prospects. He gave every man his ear but few his voice.

Rutherford's specific instance, demonstrating the falsity of the impression that Maclaurin gave of an "airy butterfly" doing as little as possible, concerned the grant of a further prize to Maclaurin, additional to the Smith prize, his first class honours in mathematics and his remarkably early award of a fellowship at St John's, Cambridge: ${ }^{2}$

One day in 1898 his friends got a surprise - I might also say a shock - by the notification that he had been awarded the valuable Yorke Prize for a special thesis on a subject connected with the Law [the first award for five years]. Not one of us knew that he was studying law at all.

In his prefatory remarks to that thesis, On the Nature and Evidence of Title to Realty (1901), Maclaurin identifies the defects of both judicial and legislative methods of keeping the law in touch with the spirit of the times. The judges' alterations, he said, are of a patchwork character leading to cautious and expensive forms and to conveyances being attended with such mystic rites and solemnities that not even the ministering officers could comprehend them. Nor is the work of the legislature always a much greater success. He used an architectural or engineering metaphor to make his point: ${ }^{3}$

The task of restoring an ancient building requires knowledge and skills, and so the work of carrying out reforms in the law can be safely conducted only under the guidance of those who understand thoroughly the complex structure that is undergoing repair.

1 See H G Pearson Richard Cockburn Maclaurin: President of the Massachusetts Institute of Technology 1909-1920 (Macmillan, New York, 1937) 32 ("President of the Massachusetts Institute of Technology"). For other biographical information see Sir Robert Stout A Life to Inspire ... The Splendid Record of Richard Cockburn Maclaurin (New Zealand Times Company Limited, Wellington,1920), JC Beaglehole Victoria University College: an Essay Towards a History (New Zealand University Press, Wellington, 1949) and An Encyclopaedia of New Zealand: a Centennial History of Auckland Grammar School, 1869-1969 (Auckland, 1966), K A Trembath Ad Augusta: Auckland Grammar School 18691969 (Auckland Grammar School Old Boys' Association, Auckland, 1969) and Keith Sinclair A History of the University of Auckland 1883-1983 (Auckland University Press, Auckland, 1983) and Dictionary of New Zealand Biography (vol 3, Allen \& Unwin, Wellington, 1996). The Auckland Grammar School archives and the Fowlds papers (University of Auckland Library) contain further material; I am grateful to both institutions for providing me with copies of records and letters.

2 President of the Massachusetts Institute of Technology above n 1, 32, 39.

3 Richard C Maclaurin On the Nature and Evidence of Title to Realty (Clay, London, 1901) vi-viii. 
$\mathrm{He}$, there, proposed the possibility of greater, indeed comprehensive, knowledge by lawyers, like engineers or architects, than he allowed the theoretical scientists when a few years later, as Professor of Mathematical Physics at Columbia in giving lectures on light at the American Museum of Natural History, he quoted the famous words which Isaac Newton wrote near the end of his life about his revolutionary discoveries: ${ }^{4}$

I do not know how I may seem to the world, but, as to myself I seem to have been only like a boy playing on the seashore, and diverting myself in now and then finding a smoother pebble or prettier shell than ordinary, whilst the great ocean of truth lay all undiscovered before me.

The same passage is quoted by a Professor of Law at the University of Colorado, Paul Campos, in a recent book, the provocative character of which is shown by its title, Jurismania: The Madness of American Law. ${ }^{5}$ Campos uses the quote when challenging the claims of "dogmatic rationalists", a label which he applies to some contemporary American lawyers. ${ }^{6}$

I wish to keep in mind those words of advice, both the limiting cautionary ones about what we do or can know and the limits of reason and the contrasting expansive ones about trying to see our subject steadily and to see it whole, ${ }^{7}$ as I touch on three matters:

- huge and continuing changes in science and technology and, in part, as a consequence in ideology and political philosophy over the past century;

- related globalising, localising and privatising forces and the consequences for our law and constitution and for the ways we think about them;

- some consequences for legal education and especially for law faculties.

- My subject matter is vast. A major purpose is to suggest themes and topics for legal and related research many of which relate to three words I have just used globalising, localising and privatising. Maclaurin's own life and times confirm of course that those matters are not new.

The global element can be seen in Maclaurin's scholarship, especially in mathematics and physics, and in his scholarly community which, when he was only in his twenties,

4 The versions vary; that in President of the Massachusetts Institute of Technology above n 1, 82-83 is more elaborate.

5 Paul Campos Jurismania: The Madness of American Law (Oxford University Press, New York, 1998) ("Jurismania").

6 Jurismania above $\mathrm{n} 5, \mathrm{Ch} 4$.

7 Maclaurin used that phrase in writing to congratulate George Fowlds on his appointment as the Minister of Education in 1907; see Matthew Arnold's Sonnet to a Friend. 
already included Etienne de Villiers, later to be a senior judge in South Africa, Jan Christiaan Smuts who later unsuccessfully invited Maclaurin to organise and take charge of the educational programme of the new Union of South Africa, Lord Kelvin and other leaders of British science and, in the literary world, Edward Fitzgerald.

The localising element is illustrated by a statute of the Parliament of 1900 when the Professor of Mathematics was also teaching jurisprudence and constitutional law. That statute is the Maori Councils Act which I mention later.

And the privatising or private element is demonstrated by the University to which Maclaurin gave the final decade of his great life, the Massachusetts Institute of Technology, an institution which continues to carry out major public functions.

\section{CHANGES IN SCIENCE, TECHNOLOGY, IDEOLOGY AND PHILOSOPHY}

Many others, including Anthony Giddens in his recent outstanding Reith Lectures, have spoken about the astonishing changes in science, technology, ideology and philosophy over the past century, changes which appear to be continuing at breakneck speed. To provide a basis for some broader comments bearing on the law, I mention weaponry, communications and finance, and related moves to the privatisation of public functions.

Exactly one hundred years ago, the first international peace conference was being held in The Hague. The treaties drawn up there prohibited and regulated the use of certain weapons in warfare. It could not of course anticipate some of the weapons of mass destruction which have since been developed. It could not have anticipated even the early development of the types of aerial warfare which Maclaurin helped facilitate at MIT by establishing courses in aeronautical engineering and, in late 1914, by constructing the first wind tunnel and aeronautical laboratory in an American university. The application of science to war became even more prominent at MIT in the following years of the Great War as Maclaurin successfully impressed on officials of the War Department that, as he put it, in many of its agencies modern warfare was nine-tenths engineering. He soon had 400-500 army and naval officers attending the school of aeronautics, for instance.

But the 1899 Conference could and did state general principles which remain valid today, as appears, for instance, from the opinion of the International Court given three years ago on the lawfulness of the use of nuclear weapons. ${ }^{8}$ That court drew on the principle that the means and methods of warfare are not unlimited. "Even wars have their limits" is the slogan of the International Committee of the Red Cross for this year. Two of

8 "Legality of the Threat on Use of Nuclear Weapons" (1996) ICJ Reps 226, 256-260. 
the principles stated then and reaffirmed since are that unnecessary suffering is prohibited, and that combatants must distinguish between combatants and non-combatants and between military targets and civilian objects.

Those general principles, while necessary to mitigate the severity of war as far as possible, are plainly not sufficient, and the efforts of the past century to prepare specific prohibitions and regulations and especially to have them properly implemented must obviously continue into the next - it is to be hoped with greater success. The principles themselves have also to be supplemented as humanity's capacity for destruction increases, as with the prohibition on methods of warfare causing widespread, long term and severe damage to the environment. That is a process in which members and former members of this Faculty of Law, including Sir John Salmond and Professor R Q Quentin-Baxter, have participated.

Like weaponry, communications have gone through a revolution over the century, a revolution which shows no sign of abating. For the most part those changes are benign, although consider the vulnerability captured in the expressions "cyberwarfare" and "the Y2K bug". Figures relating to three matters help capture the magnitude of the change.

In 1900, only one in 100 New Zealanders had a telephone and overseas telecommunications were limited to very expensive telegrams - about 170 a day. It is not enough to compare the present number of telephones or telephone calls or fax messages with those tiny figures. We have as well to take account of the qualitative revolution involved in the unbundling of information from its physical carrier. A recent article in the Harvard Business Review recounts the devastation of the Encyclopaedia Britannica by CD ROMs and argues that new technology can remove the standard trade off between richness and reach involved in the physical delivery of information. ${ }^{9}$ The encyclopaedia example can be paralleled by the fate of the great American railways which in the nineteeenth century generated huge wealth and many millionaires but which failed in the twentieth century since what Americans wanted was efficient and economic transport; they were indifferent to the means. A lawyer's parallel is the actual or possible replacement of court processes by other means of dispute resolution, if and as court processes become unnecessarily expensive, formal or complex, given the parties' interests. ${ }^{10}$

While some international trade and investment statistics have not altered greatly from one end of the century to the other, some of them have, beyond belief. The

9 Philip Evans and Thomas S Wurster "Strategy and the New Economics of Information" [Sept-Oct 1997] Harv Bus Rev 71.

10 For example, see Jurismania above n 5, 179-181. 
communications revolution means that foreign exchange dealings now amount to about US\$1.5 trillion each day; in only four days, on my calculation, those dealings match the annual total of foreign trade. Those transactions have now, it seems, largely escaped national controls and are regulated, to the extent they are regulated, primarily by privately established law. Again, these developments are not necessarily benign. Kofi Annan, the United Nations Secretary-General, has referred to the uncivil society, in cataloguing international money laundering, corruption and trading in arms, drugs and people. Some of that business is vast; the value of the illegal international drug market may exceed that of international tourism. ${ }^{11}$

International tourism, or rather international travel involving New Zealand, provides my final figure: about four million people travel in and out of New Zealand each year on about 26 airlines. While Maclaurin travelled extensively in the years he was in Wellington he was a rare exception. And he could not contemplate going to Europe and back in a week.

Those areas of weaponry and communications highlight both the globalisation and the privatising of lawmaking and law application - and also the accompanying deregulation. That absence and withdrawal of state law raises basic questions of ideology and principle about the role of the state, acting not just nationally, but also internationally, through regional processes (as under the Closer Economic Relations Agreement between New Zealand and Australia) or functionally (as under the Organisation for Economic Cooperation and Development) or multilaterally (as under the United Nations and its specialised agencies). The questions include huge questions about human survival. I now consider some consequences of these changes so far as legal processes are concerned.

\section{SOME CONSEQUENCES, LEGAL AND PHILOSOPHICAL}

The consequence of these and related changes for the role of the state, for the divide between the public and for the private and public processes of social ordering, including law making, are vast. I mention two issues briefly and say a little more about a third.

\section{A International Law Making and Implementation}

Parliament and the government have recently accepted the need for greater transparency and parliamentary participation in the acceptance of certain treaty obligations. ${ }^{12}$ That is an important move in the direction of democratic principle and in

11 See for example Susan Strange The Retreat of the State: the Diffusion of Power in the World Economy (Cambridge University Press, Cambridge, 1996).

12 See for example Report of the Foreign Affairs, Defence and Trade Committee Review of the International Treaty Examination Process [1999] AJHR I 4E. 
reducing the democratic deficit in international law making. It recognises as well the vast impact of international law on our national law, an impact which too often is overlooked. But that development relates to only one part of the treaty process. As practices and controversies relating to the Uruguay Round of the General Agreement on Tariffs and Trade, the proposed Multilateral Agreement on Investment and Asian Pacific Economic Cooperation show, issues about consultation and participation at earlier stages, including agenda setting and treaty making processes, remain to be addressed and resolved. ${ }^{13}$ The broad issue is about democracy above the level of the nation state. As well, much more remains to be done to enhance our understanding of the role of international law in our national political, constitutional and legal systems and to improve other methods of implementation. As I have mentioned on earlier occasions, its impact can be seen throughout our statute book, beginning with the Abolition of the Death Penalty Act and the Accident Insurance Act and ending with the Weights and Measures Act and the Wool Board Act.

\section{B What is Private and What Public?}

A prior issue of principle concerns the constant question of what is private and what public. What are the matters for which states, nationally, regionally, functionally or internationally, must or may take responsibility? How are arguments about the role of the state to be addressed? Or is it simply a matter of the political will of the moment? The answer to that last question is No. The private/public line is not simply a matter of the political expediency of the moment. Some principles of an enduring character do help draw that line and deny or control claims for the withdrawal of the state. Principles can, for instance, be drawn from political and constitutional history running back over two millennia and from the existing body of international law. More scholarly work is called for in these areas - at least by the lawyers. Debates about access to the court system for instance can be informed by Magna Carta and the International Covenant on Civil and Political Rights. Anthony Giddens' broad conclusion is that our runaway world needs more, not less, government and that this must be democratic not simply at the national level but also at the regional (as in the European Union) and international levels.

\section{The Distribution of Power Within the State}

Greater political, professional and public understanding, based on sound scholarship, is also required in respect of the issues surrounding the localising example I mentioned, the Maori Councils Act 1900. Senior politicians, editorial writers and many others are often heard to say that there must be "one law for all New Zealanders" when, for instance,

13 See for example Jane Kelsey "Global Economic Policy-Making: A New Constitutionalism" (1999) 9 Otago LR 535. 
suggestions of a separate Maori justice system are put forward. The principle of equality requires that result, they say; we cannot have different laws applying to different categories of people. Those propositions have a very strong appeal. They are based on a basic national commitment to the principle of equality. But does that principle, do these propositions, lead to the result that we are in all respects governed by a single system of law?

The 1900 Act helps explain why that is not a correct result as a matter of law. I go further and say it is not even a possible result in the real world in which we live. The preamble to that Act records the wish of Maori communities to have a simple machinery of local self government by means of which they:

may be enabled to frame for themselves such rules and regulations on matters of local concernment or relating to their social economy as may appear best adapted to their own special wants.

Authority and encouragement in such laudable desires, declared Parliament, would conduce to their higher civilisation and contentment. Accordingly, elected Maori Councils were to be established and to be given certain duties and powers. The duties included formulating a plan for the Maori of the particular district that would be acceptable to them and would be adapted for stated purposes: ${ }^{14}$

(1) For ascertaining, providing, and prescribing for the observance and enforcement of the rights, duties, and liabilities, amongst themselves, of tribes, communities, or individuals of the Maori race, in relation to all social and domestic matters.

(2) For the suppression of injurious Maori customs, and for the substitution of remedies and punishments for injuries in cases in which compensation is now sought by means of such customs.

(3) For the promotion of education and instruction, both ordinary and technical, and the conduct and management of Native schools.

(4) And generally for the promotion of the health and welfare and moral well-being of the Maori inhabitants of the district.

That list plainly contemplates the possibility of the existence of rights, duties and liabilities within a district which differed from those under the general law and indeed from one council district to another.

14 Maori Councils Act 1900, s15. 
That possibility also appears from the bylaw making powers which could be made respecting many matters, including: ${ }^{15}$

(1) For the providing for the health and personal convenience of the inhabitants of any Maori village, pa, or assemblage of houses....

(3) For the suppression of common nuisances....

(5) For regulating the proceedings of tohungas, and the punishment by fine of those (whether European or Maori) who practise upon the superstition or credulity of any Maori in connection with the treatment of any disease....

(9) For the protection and management of eel-weirs and the regulation of their construction in such a manner that they shall not obstruct or impede navigation of rivers navigable by small steamers or boats; and the protection of any nets or eel-baskets from damage or destruction, and the protection of river-banks or river bush-scenery.

(10) For the control and the regulation of the management of all oyster-beds, pipi-grounds, mussel-beds, and fishing grounds used by the Maoris or from which they procure food, and from time to time to close such grounds or to protect such grounds from becoming exhausted, and to make reserves for the protection and cultivation of such shell-fish or eels and to prevent their extermination, and to restock such grounds as are in danger of extermination or exhaustion....

(13) For regulating the sale within the kaingas of goods by Indian, Assyrian, and other hawkers. ...

(19) For fixing the amount of fines to be paid by Maoris for non-compliance with or breach of all or any of the by-laws made by the Council.

Local village committees had powers of enforcement, and the fines imposed under the bylaws could be enforced. That legislation, introduced by the Native Minister Sir James Carroll, was one product of the work of the Te Aute College Students Association. It can be related in spirit, if not in legal form, both to the Treaty of Waitangi and to section 71 of the New Zealand Constitution Act 1852. Under the Treaty - as in fact in the early years after it was signed - power was divided, with the Crown having sovereignty or kawanatanga, organised Maori having rangatiratanga and individual Maori having the rights and duties of British subjects. Section 71 authorised the setting aside of districts within which:

15 Maori Councils Act 1900, s16. 
the laws, customs and usages of the aboriginal or native inhabitants, so far as they were not repugnant to the general Principles of Humanity, should for the present be maintained for the

Government of themselves, and in all their Relations to and Dealings with each other.

Aspects of the 1900 Act continue to this day, with separate Maori institutions having power to impose minor criminal penalties under section 36 of the Maori Community Development Act 1962.

Plainly, different bodies of law applying to different groups of New Zealanders and being enforced by different institutions were provided for in those measures. Another 1900 Act helps make the point that the Maori measure adapted a long accepted practice: on the day the Earl of Ranfurly assented to the Maori Councils Act he also assented to the Municipal Corporations Act which, of course, also provided for different laws to be made for different groups of New Zealanders and to be enforced by different bodies.

The Statute Book of 1900 contains three other statutes relating to the first point I made under this part of the paper. The statutes controlled the legislative power of the New Zealand Parliament or recognised practical and legal limits on it. One required the Colonial Secretary to meet the judgments of British Courts relating to investments in New Zealand government securities and made express the Imperial power to disallow New Zealand Acts injuriously affecting, in the opinion of the British Government, the rights of holders of such securities. The Post Office Act gave effect to obligations under the Universal Postal Union to deliver foreign mail. And the legislation facilitating the laying of a Pacific cable, in which the United Kingdom, Canada, New South Wales and Victoria were the other partners, was amended.

Those statutes indicate that, even at the beginning of the twentieth century, the law sometimes could be effective only if it escaped national boundaries and had a broader application. The Maori Councils and Municipal Corporations Acts, by contrast, indicate the need for smaller legal units. That is to say the political and editorial objection to separate systems is contradicted by the statute book of 1900 as well as of the present day. Such jurisdiction, I should add, does not have to be bounded by a defined territory. It can be personal - as with professional disciplinary codes or family law, or with the Maori juries and mixed juries provided for over much of our history.

\section{A PLURALISTIC VIEW OF THE SOURCES OF POWER}

I would like to move from matters arising from each of the globalising, localising and privatising forces to even larger questions about the way we see the distribution, organisation, exercise and control of power in the world. A recently published brilliant set of lectures by an Egyptian international lawyer ends with a quatrain written, as he puts it, by a great oriental thinker and admirably translated in a classical style by an occidental poet. The oriental was Omar Khayyam and the occidental, to return to the Maclaurin 
connection, was Edward Fitzgerald. Georges Abi-Saab quoted this quatrain of the Rubaiyat: ${ }^{16}$

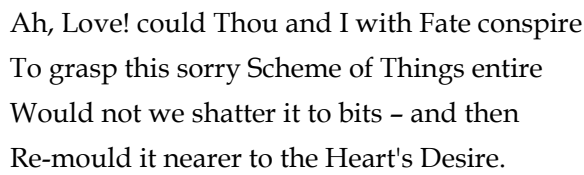

Professor Abi-Saab was lamenting the harsh reality of the world in which we live. The problem I am addressing may not be as difficult as his, for it is more in our heads than in the real world. "The Sorry Scheme of Things" that we, or at least the lawyers among us, have grown up with in our heads is a top down scheme. In brief, Parliament can make whatever law it likes and the Judges give effect to it. Subject to that proposition, the Judges also have the power to declare, develop and decide in accordance with the common law. Discussions sometimes suggest a wider judicial power, as appears for instance in Lord Justice Sedley's contention about the bi-polar sovereignty of Parliament and the Courts. ${ }^{17}$

What I am suggesting we should be considering is a much more pluralist, bottom up understanding of the distribution and exercise of power. It could even be said to be radical in a straightforward literal sense of that word. As my brief reference to the statute book indicates, in fact much law is made elsewhere than through the processes of an individual state, even if through governmental processes. Beyond those intergovernmental processes, in fact much law is made by private or non-governmental bodies subject to very little or even no governmental control. Large areas of autonomy operate and are recognised by relevant legal systems. Consider, for instance, sporting bodies operating their own law and disciplinary processes internationally as well as nationally, or universities (public as well as private), or churches, or trade organisations illustrated for instance by standard terms agreed through the International Chamber of Commerce, or the foreign exchange business mentioned earlier. In some senses there is nothing new in this. Many of those institutions and processes have their origins in actions taken long before the establishment of the modern state. The modern state has not displaced those institutions or processes - although it may now exercise some control over them. But in other senses this private or privatising element is very new - because of the pervasive and at times revolutionary effect of new technologies which have transformed and even fractured many economic, social and political structures.

16 "Cours général de droit international public" (1996) 207 Hague Recueil 9, 463, quoting 73 of the $1^{\text {st }}$ ed, 108 of the $2 \mathrm{~d}$ ed and 99 of later eds.

17 Hon S Sedley "The Sound of Silence: constitutional law without a constitution" (1994) 110 LQR 270 and S Sedley Freedom, Law and Justice (Sweet \& Maxwell, London, 1999) ch 1, especially 7-8. 
You may find a real blindness to obvious facts in this adhering, at least by lawyers, to a top down, authoritative or even authoritarian view of our law and constitution when all around us authority is challenged, power is fragmented and information has in major respects escaped state regulation and censorship. To return to Maclaurin - and Matthew Arnold - we have failed, I contend, to see things steadily and see them whole.

\section{ROLES OF LAW FACULTIES}

So far, although I have thrown out some suggestions, I have not focused expressly on the role of the University and in particular on the role of the faculty of law, its members, its students and its resources (including its library) as well as its heritage and example. This paper, like others, is to celebrate great Victorians and Victoria's excellence in teaching and research - a reminder of the essential means by which the University pursues its purposes of advancing, disseminating and maintaining knowledge. I make one comment on teaching and say rather more about research, but the academic research agenda and method must influence teaching.

\section{A Teaching}

I begin with teaching and with a rather obvious point about, first, the rapid obsolescence of much of the law which we learned, knew, practised or taught and, second, the creation of whole new bodies of law. As well, for many areas of law, lawyers and indeed others involved, now greatly helped by information technology, can look up the particular answer or at least relevant information. There is a limit to how much we must have in our heads. And yet there is obviously a core of basic principle and process which lawyers must know, understand and apply in their daily tasks. As Karl Llewellyn, a great American law teacher, once said, morals without technique is a mess while technique without morals is a menace.

What does that need to reconcile basic knowledge with rapid obsolescence mean for law teaching? I take my answer from my own experience of teaching, greatly informed by outstanding colleagues and accumulated experience of teaching over the last century or more in parts of the common law world. My answer, I was pleased to discover, is not very far from Maclaurin's. In 1911 at the Congress of Technology he gave an address which according to his biographer is his best statement of his educational ideas. William Barton Rogers, the founder 50 years earlier of MIT: ${ }^{18}$

saw clearly that the whole controversy as to the relative merits of science and the classics in the field of education missed the mark by placing the emphasis in the wrong place. He understood that when one gets to the root of things in education, the method rather than the

18 Quoted in President of the Massachusetts Institute of Technology above n 1, 293-294. 
subject is of supreme importance, and his insistence on the value of method in teaching was the cardinal doctrine in his creed and the one that has contributed most to the success of the Institute. Doubtless his knowledge of the history of science turned his thoughts in this direction. He must have pondered over the question, as every serious student has done, why throughout the ages the world stood so still in the realm of science. It was not for lack of intellectual power, for no one who has examined the matter can fail to recognize that there really were giants of old. The failure came through attacking the problems by the wrong method. And Rogers concluded that much of the failure in education was due to similar causes. What method, then, is the right one? His fundamental idea here was not original with Rogers. It has been clearly expressed before, but rarely, if ever, adopted definitely as the basis of educational method and applied systematically throughout. The idea is familiar to us all today, the idea of learning by doing. "How can a man learn to know himself?" asked Goethe. "Never by thinking, but by doing." Add to this the doctrine of Carlyle that "the end of man is an action and not a thought, though it were the noblest," and you have the whole thing in a nutshell. Carlyle is often quoted as having said that the modern university is a great library. He would have been truer to his own doctrine if he had said that the modern university is a great laboratory. "The Institute," General Walker was fond of saying, "is a place not for boys to play but for men to work." Boys and men alike learn most effectively by working for themselves, and the do-it-yourself method has been, I believe, the greatest factor in the success of this Institute of Technology.

The emphasis on process rather than on content and on learning by doing can be closely related to educational developments in the final decades of the $19^{\text {th }}$ century, for instance in the teaching at Harvard of chemistry and law. ${ }^{19}$ For law, consider the case method, in which the lawyer's library was expressly equated to the scientist's laboratory, problem methods, clinical legal education, the writing of opinions, the establishment of law reviews, mooting and much more. At Victoria, the process emphasis comes through strongly, for instance in a passage included in the faculty handbooks in the 1970s and 1980s which drew on statements prepared at Osgoode Hall Law School (largely by Professor Peter Hogg) and the College of Law at the University of Iowa. ${ }^{20}$

19 See Arthur E Sutherland The Law at Harvard: a History of Ideas and Men, 1817-1967 (Harvard University Press, Cambridge (Mass), 1967) 159 (on "Law as Science") and ch VI (The Langdell Era: 1870-1895); the President of Harvard at the relevant time - as at the time when Maclaurin was at MIT - was Charles Eliot who had been recruited in 1869 when he was 35 - from MIT where he was professor of chemistry.

20 The passage is reproduced in (1988) 18 VUWLR 341-343. 


\section{B Research}

The double emphasis in teaching on process and on learning by doing highlights the importance of facts. If I can quote Huxley again, many a beautiful theory is slain by an ugly fact. Facts are, or at least should be, critical at all stages of the legal process. That is certainly so for the resolution of particular disputes, as I learn day by day as a judge. That should be a critical element of legal education, when it addresses the process of dispute resolution or policy evaluation or development.

I mention two examples of the importance for the evaluation and development of legal policy of taking facts seriously - to borrow the subtitle of an outstanding book by a recent visitor. ${ }^{21}$ The first example is developed in that book - the law relating to personal injury. So far as the public record indicates, some recent changes in accident insurance law were advanced on unsubstantiated claims about the comparative extent of work injuries and deaths and the incentive effects of insurance premiums, against a background of general claims about the costs of ACC ballooning out of control. In the past, public policy processes in that area have been supported by more fact based, transparent processes. ${ }^{22}$

The second example is a more confined one within the same area, relating to the prevention of personal injury and death on the roads. The Attorney-General informed the House of Representatives that a proposed breath screening power in a Bill before the House was in breach of the prohibition in the Bill of Rights on unreasonable search and seizure. His opinion did not draw on available statistical material from several jurisdictions. That material indicated that the new technology led to much greater accuracy in detection, very limited interference with traffic mobility and apparently consequential falls in bad crashes. The relevant select committee considered that information and notwithstanding the Attorney's opinion recommended that the powers be conferred. They were and the road toll has continued to fall. ${ }^{23}$

21 Don Dewees, David Duff and Michael Trebilcock Exploring the Domain of Accident Law: Taking the Facts Seriously (Oxford University Press, New York, 1996). Michael Treblicock gave a lecture as part of the centenary week of the Faculty of Commerce.

22 See for example, the outstanding review by Ian Campbell in his Compensation for Personal Injury in New Zealand : its Rise and Fall (Auckland University Press, Auckland, 1997). There are encouraging signs that the most recent changes will be evaluated for their practical operation, but already there is criticism of the adequacy of the evaluation process since no points of comparison are being used; Report of the Social Services Committee [of the House of Representatives] 1999/2000 Estimates Vote Accident Insurance (19 July 1999).

23 For example, K J Keith "Road Crashes and the Bill of Rights: a Response" [1994] NZ Law Rev 115. 
Over a century ago, Oliver Wendell Holmes urged lawyers to seek an understanding of statistics and economics. ${ }^{24}$ Sir Ivor Richardson has similarly called for relevant empirical material when the courts are presented with policy arguments. In a recent paper he rather gloomily refers to areas of law in which the Courts continue to be presented with claimed facts and effects, but no evidence. He will be revisiting that issue in a paper early next month. ${ }^{25}$ While the record suggests that Holmes might be disappointed were he to contemplate this jurisdiction, there are some New Zealand examples to the contrary as I have indicated. They include an outstanding piece of empirical research being done in this faculty on the role of juries in our criminal justice system which I am sure the lawyer mathematician Maclaurin would have applauded. No doubt much more could be done.

I have mentioned facts relating to policy making. Then there are facts, in part statutory, relating to the processes of decision making and dispute resolution. The facts are statutory as well as statistical. To return to the Maori Councils Act, how are powers of decision relating to Maori issues allocated? The answer to that inquiry can suggest principles for allocation against which principles proposed on some $a$ priori basis can be tested. For instance when should decisions or policies or rules be made: ${ }^{26}$

- on a national basis - or even an international one;

- with Treaty rights or principles or some more specific right or interest being considered or being governing;

- through special institutions applying general law;

- special law;

- by agreement between the Crown and relevant Maori party; or

- by a Maori institution essentially developing its own principles and law.

The Legislation Advisory Committee has done related more general work - endorsed by the Cabinet Office Manual - on the allocation of decision making powers. That work

24 Oliver Wendell Holmes "The Path of the Law" (1897) 10 Harv L Rev 457 and Oliver Wendell Holmes "Law in Science and Science in the Law" (1899) 12 Harv L Rev 443.

25 Now published at (2000) 31 VUWLR 55.

26 For example, Report of the Royal Commission on the Electoral System Towards a Better Democracy (Government Printer, Wellington,1986) ch 3. 
and work on Maori issues, done for instance by Professor Mason Durie, provides models for further research and for practical policy proposals and development. ${ }^{27}$

A final example from the area of decision making is the operation of the law of judicial review. Work has been and is being done by the Ministry of Justice, the Law Commission and the Rules Committee. The Ministry has undertaken limited research into the use actually made of applications for review. Another important, even essential, part of that

27 Legislation Advisory Committee Legislative Change: Guidelines on Process and Content (rev ed, Department of Justice, Wellington, 1991) paras 48-142; Mason Durie Te Mana, te Kawanatanga: the Politics of Maori Self-Determination (Oxford University Press, Auckland, 1998). 
research would examine the particular and more general consequences of court decisions granting relief. Canadian and English research provide valuable models. ${ }^{28}$

I move from facts relating to decision making to facts about one particular quality of the law by which we live. It may appear to be a technical, formal matter but in my experience it is not: it is the choice between rules and standards. Should the traffic law prohibit driving at more than 50 kilometres per hour or careless, negligent or dangerous driving - or both? Should those preparing long term commercial contracts dot every "i" and cross every "t" or try to rely on broader propositions and procedures? How should the powers that the courts have to resolve certain categories of commercial disputes be stated? Should constitutional documents use particular or general language?

Those questions are of course too broad. The answer will often be both. So, while constitutions in general may state principles for an expanding future rather than rules for the passing hour they are very likely to include some exact rules, for instance fixing the maximum length of a Parliament - although even that rule may have a generally worded exception to allow for emergencies. But the questions remain critical.

While it is true that there are some instructive accounts of the practices of contract making in some areas of commerce and industry, including the balance between certainty and flexibility, no doubt much of the practice remains unexplored. ${ }^{29}$ It is also true that much legal commentary does relate to cases decided on statutes which are broadly drawn. On my rather unscientific sample down the years that commentary, does not, however, as often as it might, move back a step and ask whether the drafting choice was the correct one. It does not ask for instance whether the broader judicial power resulting from the use of a standard is justifiable or, if it is not, seek and suggest an alternative rule. On this matter, as on many others, once again the statute book as a whole is a rich source - as is

28 For example, W H Angus "The Individual and the Bureaucracy: Judicial Review - Do we need it?" (1974) 20 McGill LJ 177 (nicely complemented by works by two of his colleagues at Osgoode Hall Law School, P W Hogg "Judicial Review: How much do we need?" (1974) 20 McGill LJ 177 and H W Arthurs "Without the Law" Administrative Justice and Legal Pluralism in Nineteenth Century England (University of Toronto Press, Toronto, 1985)); and Genevra Richardson and Hazel Genn Administrative Law and Government Action: the Courts and Alternative Methods of Review (Oxford University Press, New York, 1994), Trevor Buck (ed) Judicial Review and Social Welfare (Pinter, London, 1998), de Smith, Woolf and Jowell Judicial Review of Administrative Action (5 ed, Sweet \& Maxwell, London, 1995) part VI; and Carol Harlow and Richard Rawlings Law and Administration (2 ed, Butterworths, London, 1997) chs 16 and 17 (on judicial review). For a similar early New Zealand review of several areas of the work of the Ombudsman see (1982) 12 VUWLR 205-324 (D J Shelton (ed)).

29 See the classic study by Stewart Macaulay "Non Contractual Relations in Business: a Preliminary Study" (1963) 28 Am Soc Rev 55. 
the related administrative, professional and judicial experience of applying broad standards and powers.

Thus over 3,000 provisions on the statute book authorise various people including judges to make orders and take other actions "as they think fit". Of the 50 such provisions in the Companies Act 1993, one authorises the High Court to amend the constitution of a company and, under another, it can exempt the company from its obligation to buy out minority shareholders. Many of the 181 "just and equitable" provisions also appear, as they have for many years, in commercial and property legislation, for instance in the powers to wind up corporate bodies. Their very existence and acceptance over a long period are relevant to criticisms of the courts based on the uncertainty which is said to be caused by tests of fairness inappropriately established by the judges. Such broad standards can be traced back a very long time. In what may be the first study of business ethics published in the western world, Johannes Nider in his De Contractibus Mercatorum On the Contracts of Merchants published in about $1468^{30}$ entitled his first chapter "How Many Things are Required for Buying and Selling Justly". The Dominican father, drawing on extensive religious teachings, does state some rules, for instance in terms of weights and measures (citing Deuteronomy), but also he requires compliance with broader standards, for instance in terms of a "just price", with certain associated broadly stated obligations of disclosure. He then assigns his whole second chapter to the issues of valuation.

Scholarly research should and sometimes does run beyond the legislative choices and the judicial interpretation of them to the impact in practice of different formulations. Consider for instance the helpful surveys of redundancy provisions in employment contracts on which the Court of Appeal was able to draw in 1998 when addressing that topic. $^{31}$

You might say that by sticking to facts, decision making processes and drafting, I am avoiding issues of principle and policy and the role of lawyers, especially in the university, in proposing and elaborating them. To recapitulate, I have, I think, already suggested a number of ways in which lawyers can help establish policy and principle, for instance by examining relevant facts, legislation, international obligations and history. Injury prevention and compensation is an outstanding example, where members of this faculty have played a real part in the creation of policy through scholarly and advisory work. A

30 Johannes Nider On the Contracts of Merchants trans Charles H Reeves, ed Ronald B Shuman (Oklahoma University Press, 1966).

31 Aoraki Corporation Ltd v McGavin [1998] 3 NZLR 276, 277 (CA). 
second way is through the study of the essentials and the details of legal processes. In Lon Fuller's splendid phrase we should there be able to find the internal morality of the law.

Then there is the critical role of the members of the university in directly addressing matters of substance and of policy, a role which can also be constructive and which may engage the social conscience. Fifty years ago, a former Dean of Law spoke of legal development being consciously and rationally directed towards the fulfilment of a progressively higher conception of civilisation. He saw social control as being carried on, at least in part, on a basis of reason and towards what is believed to be the general interest. He went on: ${ }^{32}$
Unless conflicts are to be resolved by sheer force, there must be patience and tolerance in hearing claims, in argument, in negotiation, in reconciliation. Together with this attitude two essential attributes are needed. The widest knowledge of affairs and of the particular field of inquiry is one. To this the university can make an increasingly important contribution. The other is a set of moral standards which will, for instance, discourage the quest of privilege, and by which alternative programmes and competing ideals can be valued. The university is only one (and it seems to me a relatively minor one) of the agencies that shape the social conscience; but it has an indispensable function in subjecting specific proposals to the acid test of motive, in analysing with calmness and detachment the emotional pleas which seem to sway the electorate, and employing in the discussion of projects and opinions a comparative technique which balances a narrow or parochial claim with considerations from a wider sphere of reference. Whether the question is capital punishment or the adoption of the Statute of Westminster, the law of divorce or government by Order in Council, a university can rise to its full status by informed, impartial discussion of the issues, and can affect the shape of things to come by the attitude which infuses the whole of its legal training.

I add one example to Professor Campbell's list and briefly elaborate on it: open government. It is a subject with which members and former members of the faculty have struggled as scholars in their teaching and writing, as counsel, as advisers, in submissions to parliamentary committees, as a Minister and as judges. A detailed account would pursue the differing scope and potential of each of those different roles. Let me make five summary points:

- lawyers in their scholarly writing have a greater freedom in finding the right question to ask than do the others in the list, as with Warren and Brandeis on privacy, ${ }^{33}$ although there is an interesting story to be told about the terms of

32 ID Campbell "Law and the University" in Ernest Beaglehole (ed) The University and the Community: Essays in honour of Thomas Alexander Hunter (Victoria University College, Wellington, 1946) 153.

33 S Warren and L Brandeis "The Right to Privacy" (1890) 4 Harv L Rev 193. 
reference for the Danks Committee as well as about those for the Woodhouse Commission; and the very process of such an inquiry can lead to whole new ways of seeing the matters.

- academics also have a greater freedom to challenge the existing orthodoxy than the others, first, by their organisation and classification of the law as a whole or particular parts of it - as with Blackstone generally or Goff and Jones on restitution ${ }^{34}$ - or, second, by their reassertion of principle as with Stanley de Smith on the openness associated with natural justice, soon endorsed by Lord Reid. ${ }^{35}$

- academics also have a greater freedom in a third way to challenge the orthodoxy by calling for the reversal of existing principle, as with calls for the reversal or at least the substantial narrowing of the principle underlying official secrets legislation; ${ }^{36}$ or, to revert to a topic mentioned earlier, the abolition of all or parts of the law of negligence - possibly accompanied by compulsory first party insurance. ${ }^{37}$

- academics should have access to wider sources of information than some in the list, because of their interdisciplinary opportunities and of the different constraining rules and practices governing the information which courts consider. I would stress, to return to Maclaurin, the great value of learning from colleagues from other disciplines; those processes have certainly helped the reform of official information law in New Zealand.

- academics can examine the big picture and the underlying principles with greater freedom. Judges, law reformers and other advisers may be able to agree on a result without necessarily agreeing on or indeed even addressing those larger matters; those matters are truly for the scholars to debate - and perhaps never to resolve. ${ }^{38}$

In support of that last proposition about an essential, perhaps unique role of the scholar I end, as I began, with Maclaurin. In his immensely busy life, he managed to find

34 Robert Goff and Gareth Jones The Law of Restitution (4ed, Sweet \& Maxwell, London, 1993).

35 S A de Smith "The Right to a Hearing in English Administrative Law" (1955) 68 Harv L Rev 569 incorporated in the first (1959) edition of Constitutional and Administrative Law (Longman, London, 1959) and in Ridge v Baldwin [1994] AC 40.

36 For example, David Williams Not in the Public Interest: the Problem of Security in Democracy (Hutchinson, London, 1965).

37 For example, John Smillie "Formalism, Fairness and Efficiency: Civil Adjudication in New Zealand" [1996] NZ L Rev 254 and Geoffrey Palmer "The Design of Compensation Systems: Principles Rule, OK?" (1995) 29 Valparariso L Rev 1115.

38 For example, Cass R Sunstein Legal Reasoning and Political Conflict (Oxford University Press, New York, 1998). 
time to write a parody of a report from a learned body on university research, a report, he said, written from the point of view of a man who is used to reporting on the efficiency of a glue factory or a soap works. One "gauge of efficiency" used in the report was the cost of a student hour. The relevant official calls upon Mr Isaac Newton: ${ }^{39}$

Superintendent of Buildings and Grounds: Your theory of gravitation is hanging fire unduly. The director insists on a finished report, filed in his office by 9 am Monday next, summarized on one page, typewritten, and the main points underlined. Also, a careful estimate of the cost of the research a student hour.

Newton: But there is one difficulty that has been puzzling me for fourteen years, and I am not quite -

Superintendent of Buildings and Grounds (with snap and vigor): Guess you had better overcome that difficulty by Monday morning or quit.

39 Quoted in President of the Massachusetts Institute of Technology above n 1, 167. 
